\title{
Perlindungan Saksi Dan Korban
}

\author{
Nenden Herawaty $S$
}

\section{Pendahuluan}

Manusia sebagai mahkluk sosial yang mempunyai rasa kepedulian terhadap sesama dan lingkungan mempunyai kewajiban melakukan interaksi yang baik diantara kelompok masyarakat itu sendiri. Sebagai warga Negara yang baik dan patuh terhadap hukum maka wajarlah jika kita patuh dengan aturan yang berlaku dalam masyarakat. Perilaku manusia tercermin dari kebiasaan yang sering dilakukan oleh manusia itu sendiri dalam kehidupan sehari-hari. Kebiasaan yang dilakukan berulang-ulang dapat dikategorikan sebagai adat kebiasaan dari orang/masyarakat. Jika kita telaah kebiasaan yang tumbuh dalam masyarakat seringkali dapat menimbulkan konflik apabila tidak dibingkai dalam satu produk perundangaundangan. Kebiasaan orang untuk melakukan perbuatan melawan hukum tidak dapat disamakan dengan kelompok yang patuh terhadap hukum. Seringkali jika kita amati. Salah satu kepatuhan terhadap hukum yang dapat kita jumpai dalam kehidupan masyarakat adalah dengan mengikuti/patuh terhadap aturan yang ada. Walaupun seringkali menyimpang dari aturan ada. Rasa ingin tahu seringkali mendorong kita untuk melakukan hal yang diluar batas kesadaran. Sadar kita berada dalam satu komunitas yang benar atau salah tergantung dari bagaimana kita memandang serta menyikapi sesuatu. Apabila terjadi peristiwa hukum maka yang pertama-tama yang menjadi pertanyaan masyarakat adalah ada apa masalahlah ? siapa yang menjadi korban? Siapa pelakuknya? dan asiap yang, melihat peristiwa tersebut?

Seringkali kebanyakan masyarakat takut jika sudah masuk pada wilayah-wilayah hukum. Ketakutan jika melanggar hukum akan dikenai sanksi atau selalu terbayang bentuk hukum yang akan diterima. Hal ini berlaku juga dalam pemberian kesaksian. Terkadang masyarakat takut apabila diminta untuk menjadi saksi dalam satu perkara apalagi jika dipanggil oleh pihak kepolisian ataupun pengadilan. Selalu terbayang bagimana nanti akan bersikap didepan pengadilan atau polisi.

Bagaimana memotifvasi masyarakat untuk dapat berperan serta dalam penegakan hukum khususnya. Hal ini membutuhkan suatu keberanian dari masyarakat untuk berhadapan dengan hukum apabila mendengar jika ia dikaitkan sebagai saksi dalam permasalahan hukum. Satu hal yang perlu diketahui bagi mereka yang dalam posisi sebagai saksi adalah keberanian untuk menggungkapkan kebenaran yang diketahuinya secara langsung. Hal ini dapat dilakukan apabila didukung dengan produk perundang-undangan. Kadangkala seseorang yang mengetahui duduk masalah/ peristiwa yang terjadi takut apabila dimintakan keterangan, dengan alasan jangan sampai saksi ini menjadi tersangka/apelaku tindak pidana. Ketika kebenaran akan terungkap maka ada pasti ada orang yang merasa terancam dengan kesaksian yang diberikan oleh saksi. Atas dasar inilah maka penulis mengangkat bagaimana perlindungan saksi dan korban menurut hukum yang berlaku di Indonesia ? perlindungan ini dibuthkan bagi mereka yang menjadi saksi maupun korban sehingga penegakan hukum dapat laksanakan tanpa memandang siapa pelaku maupun korban.

Seringkali orang tidak bersedia untuk memberi kesaksian dihadapan aparat polisi, jaksa dan hakim karena mereka merasa takut dengan jangan-jangan mereka akan dijadikan Tersangka 
apabila tidak dapat memberikan keterangan yang diminta. Dan ketakutan ini dianggap wajar apabila mereka dibawah tekanan dalam memberikan kesaksian dihadap aparat tersebut. Ada juga yang berpandangan apabila mereka memberikan kesaksian maka nyawa mereka akan terancam, sehingga daianggap perlu untuk memberikan perlindungan terhadap saksi-saksi dan korban yang mengalami tindakan melawan hukum. Aturan yang jelas akan membantu serta memberikan ruang kepada mereka yang peduli terhadap penegakan hukum untuk dapat melakukan kewajibannya sebagai warga Negara yang patuh terhadap hukum.

\section{Pembahasan}

Pengertian dari bukti, membuktikan, terbukti dan pembuktian menurut WJS. Poerwardarminta, sebagai berikut:

- Bukti adalah sesuatu hal (peristiwa dan sebagainya) yang cukup untuk memperlihatkan kebenaran sesuatu hal (peristiwa dan sebagainya);

- Tanda bukti, barang bukti adalah apa-apa yang menjadi tanda sesuatu perbuatan (kejahatan dan sebagainya).

- Membuktikan mempunyai pengertian-pengertian:

1. Memberi (memperhatian) bukti;

2. Melakukan sesuatu sebagai bukti kebenaran, melaksanakan (cita-cita dan sebagainya);

3. Menandakan, menyatakan (bahwa sesuatu benar);

4. Menyakinkan, menyaksikan.

- Pembuktian adalah perbuatan (hal dan sebagainya) membuktikan.

Dalam pengertian yuridis, tentang bukti dan alat bukti dapat disimak pendapat Prof.Soebekti yang menyatakan, "bukti adalah sesuatu untuk meyakinkan akan kebenaran suatu dalil atau pendirian. Alat bukti, meyakinkan akan kebenaran suatu Bewijs middle (Bld) adalah alat-alat yang dipergunakan untuk dipakai membuktikan dalil-dalil suatu pihak di muka pengadilan, misalnya bukti-bukti tukisan, kesaksian, persangkaan, sumpah dan lain-lain.”

Pengertian "membuktikan" dari WJS. Poerwadarminta di atas dapat dikatakan sebagai pengertian umum (tidak yuridis), sedangkan membuktikan dalam arti yuridis menurut Prof. Dr. Soedikno Mertokusumo "Tidak lain berarti memberi dasar-dasar yang cukup kepada Hakim yang memeriksa perkara yang bersangkutan guna member kepastian tentang kebenaran peristiwa yang diajukan." Prof.Soedikno juga berpendapat bahwa membuktikan mengandung tiga pengertian yaitu membuktikan dalam arti logis, membuktikan dalam arti konvensional dan membuktikan dalam Hukum Acara mempunyai arti yuridis.

Sehubungan dengan istilah bukti dan alat-alat bukti ini Dr.A.Hamzah,SH, memberikan batasan yang hampir sama dengan pendapat Prof.Subekti,SH. Dikemukakan oleh Dr.A.Hamzah,SH bukti yaitu "sesuatu untuk menyakinkan kebenaran suatu dalali, pendirian atau dakwaan. Alatalat bukti ialah upaya pembuktian melalui alat-alat yang diperkenankan untuk dipakai membuktikan dalil-dalil atau dalam perkara pidana dakwaan di sidang pengadilan, misalnya keterangan terdakwa, kesaksian, keterangan ahli, surat dan petunjuk dalam Pekara Perdata termasuk persangkaan dan sumpah."

\footnotetext{
${ }^{1}$ Bambang Waluyo, Sistem Pembuktian Dalam Peradilan Indonesia (Cet I; Jakarta: Sinar Grafika, 1992), h. 1-
} 
Menurut Prof.Dr.Soedikno Mertokusumo, tiga teori pembuktian dalam Hukum Acara Perdata yaitu :

1. Teori Pembuktian Bebas

Teori ini tidak menghendaki adanya ketentuan-ketentuan yang mengikat hakim, sehingga penilaian pembuktian seberapa dapat diserahkan kepadanya.

2. Toeri Pembuktian Negatif

Menurut teori ini harus ada ketentuan-ketentuan yang mengikat yang bersifat negative, yaitu bahwa ketentuan ini harus membatasi pada larangan kepada hakim untuk melakukan sesuatu yang berhubungan dengan pembuktian. Jadi hakim disini dilarang dengan pengecualian (Pasal 169 HIR, 285 Rbg, 1905 BW).

3. Toeri Pembuktian Positif

Disamping adanya larangan, teori ini menghendaki adanya perintah kepada hakim. Disini hakim diwajibkan, tetapi dengan syarat ( Pasal $165 \mathrm{HIR}, 285 \mathrm{Rbg}, 1870 \mathrm{BW}$ ).

Menurut UU No. 13/ 2006 Pasal 1 ayat (1) Saksi adalah orang yang dapat memberikan keterangan guna kepentingan penyelidikan, penyidikan, penuntutan dan pemeriksaan di sidang pengadilan tentang suatu perkara pidana yang ia dengar sendiri, ia lihat sendiri, dan/atau ia alami sendiri. Ayat (2) Korban adalah seseorang yang mengalami penderitaan fisik, mental, dan/atau kerugian ekonomi yang diakibatkan oleh suatu tindak pidana. Ayat (3) Lembaga Perlindungan Saksi dan Korban, yang selanjtnya disingkat LPSK, adalah lembaga yang bertugas dan hak-hak lain kepada saksi dan/atau korban sebagaimana diatur dalam undang-undang ini. Ayat (4) Ancaman adalah segala bentuk perbuatan yang menimbulkan akibat, baik langsung maupun tidak langsung, yang mengakibatkan Saksi dan/atau Korban merasa takut dan/atau dipaksa untuk melakukan atau tidak melakukan sesuatu hal yang berkenaan dengan pemberian kesaksiannya dalam suatu proses Peradilan Pidana. Ayat (5) Keluarga adalah orang yang mempunyai hubungan darah dalam garis lurus ke atas atau ke bawah dan garus menyamping sampai derajat ketiga, atau orang yang menjadi tanggungan Saksi dan/atau Korban. Ayat (6) Perlindungan adalah segala upaya pemenuhan hak dan pemberian bantuan untuk memberikan rasa aman kepada Saksi dan/atau Korban yang wajib dilaksanakan oleh LPSK atau lembaga lainnya sesuai dengan ketentuan UU ini. ${ }^{3}$

Perlindungan saksi dan korban berasaskan pada :

a. Penghargaan atas harkat dan martabat manusia

b. Rasa aman;

c. Keadilan;

d. Tidak diskriminatif; dan

e. Kepastian hukum ${ }^{4}$

Perlindungan saksi dan korban bertujuan memberikan rasa aman kepada Saksi dan/atau Korban dalam memberikan keterangan pada setiap proses Peradilan Pidana.

Menurut UU No. 9 Tahun 2004 Pasal 1 Atas permintaan salah satu pihak, atau karena jabatannya, Hakim Ketua sidang dapat memerintahkan seorang saksi untuk didengar dalam persidangan. Pasal 2 Apabila saksi tidak datang tanpa alasan yang dapat dipertanggungjawabkan meskipun sudah dipanggil dengan patut dan Hakim cukup mempunyai alasan untuk menyangka

\footnotetext{
${ }^{2}$ Ibid., h. 7.

${ }^{3}$ UU No. 13 Tahun 2006 Tentang Perlindungan Saksi dan Korban.

${ }^{4}$ UU No. 13 Tahun 2006, Tentang Perlindungan saksi dan Korban Pasal 3 dan Pasal 4.
} 
bahwa saksi sengaja tidak datang, Hakim Ketua sidang dapat member perintah supaya saksi dibawaoleh Polisi ke Pengadilan. Pasal 3, Seorang saksi yang tidak bertempat tinggal di daerah hukum Pengadilan yang bersangkutan tudak diwajibkan dating di Pengadilan tersebut, tetapi pemeriksaan saksi itu dapat diserahkan kepada Pengadilan yang daerah hukumnya meliputi daerah kediaman saksi.

Yang tidak boleh didengar sebagai saksi adalah :

a. Keluarga sedarah atau semenda menurut garis keturunan lurus ke atas atau ke bawah sanpai derajat kedua dari salah satu pihak yang bersengketa;

b. Istri atau suami slah seorang pihak yang bersengketa meskipun sudah bercerai;

c. Anak yang belum berusia tujuh belas tahun;

d. Orang sakit ingatan. ${ }^{5}$

Yang boleh diperiksa untuk memberi keterangan tanpa sumpah ialah:

a. Anak-anak yang umurnya belum cukup 15 (lima belas) tahun dan belum pernah kawin;

b. Orang sakit ingatan atau sakit jiwa meskipun kadang-kadang ingatannya kembali. ${ }^{6}$

Orang dapat meminta pengunduran diri dari kewajiban untuk memberi kesaksian ialah :

a. Saudara laki-laki dan perempuan, ipar laki-laki dan perempuan salah satu pihak;

b. Setiap orang yang karena martabat, pekerjaan atau jabatannya itu. ${ }^{7}$

Menjadi saksi adalah salah satu kewajiban hukum setiap orang. Orang yang dipanggil menghadap sidang Pengadilan untuk menjadi saksi tetapi menolak kewajiban itu dapat diperiksa untuk dihadapkan di persidangan dengan bantuan polisi.

UU No. 31/1997 tentang Peradilan Militer Pasal 100 ayat (1) Setiap orang yang menjadi korban atau yang mengalami atau menyaksikan atau melihat dan/atau mendengar secara langsung tentang terjadinya tindak pidana yang dilakukan oleh seseorang sebagaimana dimaksudkan dalam Pasal 9 angka 1 berhak mengajukan laporan atau pengaduann kepada penyidik baik lisan maupun tulisan. Ayat (2) setiap orang yang mengetahui permufakatan jahat yang dilakukan oleh seseorang sebagaimana dimaksud dalam Pasal 9 angka 1 untuk melakukan tindak pidana terhadap hak milik, wajib seketika itu juga melaporkan hal tersebut kepada penyidik atau atasan yang berwenang. Ayat (3) Sesudah menerima laporan, Penyidik harus membuat surat tanda terima laporan atau pengaduan, diberikan kepada yang bersangkutan dengan ditandatangani oleh pelapor dan penerima laporan.

Menurut UU No. 31/1997 Pasal 108 ayat (1) keterangan tersangka dan/atau saksi kepada penyidik diberikan tanpa tekanan dari siapapun dan/atau dalam bentuk apapun. Ayat (2) penyidik mencatat semua keterangan tersangka dan/atau saksi dalam berita acara secara teliti sesuai dengan kata-kata yang dipergunakan oleh Tersangka atau Saksi. Ayat (3) Keterangan tersangka dan/atau saksi dicatat dalam berita acara sebagaimana dimaksud pada ayat (1) dan ditandatangani oleh penyidik dan oleh yang member keterangan sesudah mereka menyetuji

\footnotetext{
${ }^{5}$ UU No. 9/2004 Tentang Peradilan Militer Pasal 87.

${ }^{6}$ UU No.31/1997 Tentang Peradilan Militer Pasal 163.

${ }^{7}$ UU No.9/2004 Tentang Peradilan Tata Usaha Negara Pasal 88.
} 
isinya. Ayat (4) dalam hal tersangka dan/atau saksi tidak mau membubuhkan tandatangannya, peyidik mencatat hal itu dalam berita acara dengan menyebut alasannya.

UU No. 31/1997 Pasal 155 ayat (1) apabila saksi sesudah mmebri keterangan dalam penyidikan meninggal dunia atau karena halangan yang sah tidak hadir disidang atau tidak dapat dipanggil karena jauh tempat tinggalnya atau karena sebab lain yang berhubungan dengan kepentingan Negara, keterangan yang sudah diberikan itu dibacakan. Ayat (2) apabila keterangan itu sebelumnya sudah diberikan di bawah sumpah, keterangan itu disamakan nilainya dengan keterangan Saksi di bawah sumpah yang diucapkan di sidang.

Apabila keterangan saksi di sidang berbeda dengan keterangan yang terdapat dalam berita acara, Hakim Ketua mengingatkan saksi tentang hal itu serta meminta keterangan mengenai perbedaan yang ada dan dicatat sumpah yang diucapkan di sidang. ${ }^{8}$

Pasal 161 ayat (1) mereka yang karena pekerjaan, harkat martabat atau jabatannya diwajibkan menyimpan rahasia, dapat meminta dibebaskan dari kewajiban untuk memberikan keterangan sebagai saksi tentang hal yang dipercayakan kepadanya menurut ketentuan peraturan perundangundangan yang berlaku. Ayat (2) Hakim menentukan sah atau tidaknya segala alasan untuk permintaan tersebut.

Pasal 164 ayat (1) Apabila keterangan saksi di sidang diduga palsu, Hakim Ketua memperingatkan dengan sungguh-sungguh kepadanya supaya memberikan keterangan yang sebenarnya dan mengemukakan ancaman pidana yang dapat dikenakan kepadanya apabila ia tetap memberikan keterangan palsu. Ayat (2) Apabila saksi tetap pada keterangannya itu, Hakim Ketua karena jabatannya atau atas permintaan Oditur atau Terdakwa dapat member perintah penahanan kepada saksi untuk selanjutnya dilakukan penyidikan dan dituntut perkara dengan dakwaan sumpah palsu.

Masalah merahasiakan kedudukan, pekerjaan dan jabatan memang bercorak hukum public yang bertujuan bila ditinjau dari segi hokum public adalah yang bersangkutan wajib melindungi kepentingan masyarakat, bukan untuk melindungi kepentingan individu-individu pemuka masyarakat atau pejabat yang bersangkutan. Dengan demikian mereka tidak boleh melindungi kepentingan individu bertamengkan kepentingan umum, bila terjadi demikian maka hak mengundurkan diri sebagai saksi harus ditegakkan berdasar patokan pertimbanganpertimbangan:

a. Sejauhmana terlindungi kepentingaN umum, bila mereka mempergunakan hak mengundurkan diri menjadi saksi.

b. Seberapa besar bahaya yang mengancam kepentingan umum, bila mereka menjadi saksi.

Banyak kalangan pada era reformasi sekarang ini yang berpendapat bahwa secrei absolute yang mengagungkan rahasia jabatan harus digeser, dengan alasan-alasan :

a. Pada eforia era reformasi menuntut keterbukaan (full transparency).

b. Dalam suasana kongkrit, berbicara, memberikan keterangan tentang sesuatu jauh lebih penting bagi perlindungan umum dari pada hal itu tertutup dan dirahasiakan,sebagai contoh notaries (PPAT) yang menemukan sertifikat palsu atau ganda, dalam hal ini dapat

\footnotetext{
${ }^{8}$ UU No. 31/1997 Tentang Peradilan Militer Pasal 156, 162 dan 164.
} 
dipertanyakan, mana yang lebih baik untuk kepentingan perlindungan umum, notaries (PPAT) yang menemukan sertifikat palsu atau ganda, dalam hal ini dapat dipertanyakan, mana yang lebih baik untuk kepentingan perlindungan umum, notaris mengundurkan diri sebagai saksi, sehingga rahasia kepalsuan sertifikat tersebut tetap terpendam dari pada rahasia kepalsuan itu dibuka kepada umum, sudanh barang tentu lebih kepalsuan itu dibuka notaries secara transparan, agar masyarakat dapat terlindungi, jika begitu dalam kasus notaris mempergunakan hak mundur sebagai saksi berarti penggunaan itu sangat bertolak belakang dengan kewajiban rahasia jabatan pada sisi dan kepentingan umum, pada sisi lain, dengan demikian penegakan kewajiban menyimpan rahasia, kedudukan, pekerjaan, jabatan absolute, totalitas terkandung jauh lebih besar bahayanya kepada kepentingan umum. ${ }^{9}$

Pasal 242 ayat (1) barangsiapa dalam keadaan dimana UU menentukan supaya memberi keterangan di atas sumpah atau mengadakan akibat hukum kepada keterangan yang demikian dengan sengaja memberi keterangan palsu di atas sumpah, baik dengan lisan atau tulisan, secara pribadi maupun oleh kuasanya yang khusus ditunjuk untuk itu, diancam dengan Pidana penjara paling lama tujuh tahun. Ayat (2) jika keterangan palsu diatas sumpah diberikan dalam perkara pidana dan merugikan terdakwa atau tersangka, yang bersalah diancam dengan pidana penjara paling lama sembilan tahun. ${ }^{10}$

Perlindungan bagi saksi dan korban sangat dibutuhkan dalam hal penegakan supremasi hukum sehingga dapat mengungkap kebenaran yang sesungguhnya terjadi. Seseorang jika menjadi saksi jika dapat memberikan keterangan dibawah sumpah dan yang harus diperhatiakn adalah saksi harus berada, mendengar dan melihat kejadian yang terjadi di tempat kejadian (TKP/locus dekicti). Apabila saksi yang diajukan atau karena kesadarannya sendiri memberikan keterangan baik yang bertentangan ataupun tidak bertentangan dengan rasa keadilan tetap didengar kesaksiannya. Dan apabila saksi ini berkata dengan benar maka perlu ada perlindungan bagi saksi tersebut.

UU No. 13 Tahun 2006 Pasal 5 ayat (1) menyatakan bahwa seorang saksi dan Korban berhak :

a. Memperoleh perlindungan atas keamanan pribadi, keluarga dan harta bendanya, serta bebbas dari ancaman yang berkenaan dengan kesaksian yang akan, sedang, atau telah diberikannya;

b. Ikut serta dalam proses memilih dan menentukan bentuk perlindungan dan dukungan keamanan;

c. Memberikan keterangan tanpa tekanan;

d. Mendapat penerjemah

e. Bebas dari pertanyaan yang menjerat;

f. Mendapatkan informasi mengenai perkembangan kasus;

g. Mendapatkan informasi megenai putusan pengadilan;

h. Mengetahui dalam hal terpidana dibebaskan;

i. Mendapat identitas baru;

j. Mendapatkan tempat kediaman baru;

\footnotetext{
${ }^{9}$ Ahmad Mujahidin, Pembaharuan Hukum Acara Perdata PA dan Mahkamah Syari'ah Indonesia, IKAHI, Jakarta, 2008, h. 270-271

${ }^{10}$ Kitab Undang-undang Hukum Pidana (KUHP)
} 
k. Memperoleh penggantian biaya transportasi sesuai dengan kebutuhan;

1. Mendapat nasihat hukum; dan/atau

m. Memperoleh bantuan biaya hidup sementara sampai batas waktu perlindungan berakhir.

Ayat (2) Hak sebagaimana dimaksud pada ayat (1) diberikan kepada saksi dan/atau korban tindak pidana dalam kasus-kasus tertenti sesuai dengan keputusan LPSK.

UU No. 13/2006 Pasal 10 (1) Saksi, Korban, dan pelapor tidak dapat dituntut secara hokum baik pidana maupun Perdata atas laporan, kesaksian yang akan, sedang, atau telah diberikannya. Ayat (2) Seorang Saksi yang juga tersangka dalam kasus yang sama tidak dapat dibebaskan dari tuntutan Pidana apabila ia ternyata terbukti secara sah dan menyakinkan bersalah, tetapi kesaksiannya dapat dijadikan pertimbangan hakim dalam meringankan Pidana yang akan dijatuhkan. Ayat (3) Ketentuan sebagaimana dimaksud pada ayat (1) tidak berlaku terhadap Saksi, Korban dan pelapor yang memberikan keterangan tidak dengan itikad baik.

\section{Penutup}

1. Perlindungan saksi dan korban bertujuan memberikan rasa aman kepada Saksi dan/atau Korban dalam memberikan keterangan pada setiap proses Peradilan Pidana

2. Barangsiapa dalam keadaan dimana UU menentukan supaya memberi keterangan di atas sumpah atau mengadakan akibat hukum kepada keterangan yang demikian dengan sengaja memberi keterangan palsu di atas sumpah, baik dengan lisan atau tulisan, secara pribadi maupun oleh kuasanya yang khusus ditunjuk untuk itu, diancam dengan Pidana penjara paling lama tujuh tahun.

\section{Daftar Pustaka}

Hamzah Andi, Kitab Undang-undang Hukum Pidana (Jakarta: Rineka Cipta, 1992).

Mujahidin Ahmad, Pembaharuan Hukum Acara Perdata PA dan Mahkamah Syari'ah Indonesia (Jakarta: IKAHI, 2008).

Waluyo Bambang, Sistem Pembuktian Dalam Peradilan Indonesia (Jakarta: Sinar Grafika, 1992).

UU No. 31/1997 Tentang Perdilan Militer.

UU No.9/2004 Tentang Peradilan Tata Usaha Negara.

UU No. 13 Tahun 2006, Tentang Perlindungan saksi dan Korban. 